\title{
OKOLICZNOŚCI USPRAWIEDLIWIAJĄCE STAN SILNEGO WZBURZENIA PRZY ZABÓJSTWIE Z AFEKTU
}

\section{Wstęp}

Typ przestępstwa zabójstwa $\mathrm{z}$ afektu funkcjonuje na gruncie polskiego prawa karnego od wielu lat. Przepis art. $148 \S 4$ Kodeksu karnego ${ }^{1}$ sankcjonujący zabójstwo pod wpływem silnego wzburzenia usprawiedliwionego okolicznościami został przez ustawodawcę $\mathrm{w}$ niezmienionym kształcie przejęty z Kodeksu karnego z 1969 r. ${ }^{2}$, w związku z czym jest on przedmiotem bogatej literatury i orzecznictwa ${ }^{3}$. Pomimo tego uznawany

* Doktorantka Katolickiego Uniwersytetu Lubelskiego Jana Pawła II; e-mail: k_zaborska@interia.pl.

1 Ustawa z dnia 6 czerwca 1997 r. - Kodeks karny, tekst jednolity: Dz. U. z 2018 r. poz. 1600 (dalej: k.k.).

2 Ustawa z dnia 19 kwietnia 1969 r. - Kodeks karny, Dz. U. z 1969 r. Nr 13, poz. 94 z późn. zm. Na gruncie niniejszej ustawy karnej zabójstwo z afektu uregulowane zostało w przepisie art. 148 § 2 k.k.

3 Uprzywilejowany typ zabójstwa z afektu funkcjonował także na gruncie Rozporządzenia Prezydenta Rzeczypospolitej z dnia 11 lipca 1932 r. - Kodeks karny, Dz. U. z 1932 r. Nr 60, poz. 571 z późn. zm. Przepis art. 225 § 2 k.k. z 1932 r. przewidywał łagodniejszą sankcję dla sprawcy zabójstwa dokonanego pod wpływem silnego wzruszenia. Przedmiotowa regulacja nie zawierała dodatkowej przesłanki w postaci konieczności usprawiedliwienia afektu. Aby przypisać sprawcy odpowiedzialność za uprzywilejowany typ zabójstwa wystarczyło ustalenie, iż w chwili jego popełnienia działał on pod wpływem silnego wzruszenia, zob. Komisja Kodyfikacyjna Rzeczypospolitej Polskiej. Sekcja Prawa Karnego, Projekt kodeksu karnego, w redakcji przyjętej w drugiem czytaniu przez Sekcje Prawa Karnego Komisji Kodyfikacyjnej R. P. Uzasadnienie części szczególnej, t. 5, z. 4, Warszawa 1930, s. 168; wyrok Sądu Najwyższego z dnia 3 kwietnia 1933 r., I K 166/33, LEX nr 389795; wyrok Sądu Najwyższego z dnia 13 stycznia 1956 r., IV K 1028/55, LEX nr 118613. 
jest, także współcześnie, za jedno z bardziej kontrowersyjnych zagadnień w prawie karnym. Wiąże się to przede wszystkim z tym, iż zabójstwo popełnione pod wpływem silnego wzburzenia usprawiedliwionego okolicznościami, jest uprzywilejowanym typem przestępstwa ze względu na szczególną sytuację emocjonalną po stronie sprawcy ${ }^{4}$.

Afekt ${ }^{5}$, który jest podstawowym znamieniem tego przestępstwa, nie jest pojęciem stricte prawnym, co na przestrzeni lat rodziło liczne spory dotyczące jego wykładni. Silne wzburzenie ujmowane jest najczęściej jako przejaw „stanu psychicznego, w którym przeżycia emocjonalne mają przewagę nad intelektem, wskutek czego sprawca działa pod przemożnym wpływem tych właśnie czynników emocjonalnych i przy wyraźnym ograniczeniu kontrolującej działalności rozumu" ${ }^{6}$. Według orzecznictwa Sądu Najwyższego afektem jest niemal odruchowa, nagła reakcja na zdarzenie stanowiące szczególnie trudny do opanowania „impuls sprawczy dla zachowania niezgodnego z prawem"7. Dla przyjęcia uprzywilejowanego typu zabójstwa konieczne jest wystąpienie afektu o wysokim stopniu natężenia. Przepis art. 148 § 4 k.k. stanowi bowiem o „silnym wzburzeniu". Jak trafnie wskazał W. Wolter, wzburzenie jest wtedy silne, kiedy człowiek dopuścił się czegoś, czego nigdy nie zrobiłby bez wzburzenia ${ }^{8}$. Jest to definicja uproszczona, ale $\mathrm{w}$ pełni oddająca istotę stanu silnego wzburzenia. Jako jej rozwinięcie można przytoczyć rozważania A. Zolla, zdaniem którego „afekt fizjologiczny musi być tak silny, że wywołuje

4 Zob. wyrok Sądu Apelacyjnego w Katowicach z dnia 3 kwietnia 2014 r., II AKa 63/14, LEX nr 1461041.

5 Na potrzeby niniejszej publikacji definicja stanu silnego wzburzenia została podjęta jedynie skrótowo. Szerzej na temat pojęć afektu i silnego wzburzenia, zob. K. Daszkiewicz, Przestęstwa z afektu w polskim prawie karnym, Warszawa 1982; S. Cora, Zabójstwo pod wptywem silnego wzburzenia w świetle prawa i psychologii, „Nowe Prawo” 1973, nr 7/8, s. 10261039; W. Król, Silne wzburzenie w rozumieniu art. 148 § 4 k.k., "Prokuratura i Prawo” 2009, nr 9, s. 45-65; A. Golonka, Stan silnego wzburzenia jako znamię zabójstwa typu uprzywilejowanego czy okoliczność wptywająca na zmniejszenie poczytalności sprawcy przestępstwa?, „Palestra” 2014, nr 3/4, s. 65-75; K. Wiak [w:] K. Wiak, A. Grześkowiak (red.), Kodeks karny. Komentarz, Warszawa 2018, s. 863-866; R. Kokot [w:] R.A. Stefański (red.), Kodeks karny. Komentarz, Warszawa 2017, s. 909-910.

6 Wyrok Sądu Najwyższego z dnia 13 lutego 1973 r., V KRN 567/72, LEX nr 64179.

7 Postanowienie Sądu Najwyższego z dnia 14 kwietnia 2011 r., II KK 71/11, LEX nr 794969.

8 Zob. W. Wolter [w:] I. Andrejew, W. Świda, W. Wolter, Kodeks karny z komentarzem, Warszawa 1973, s. 439. 
reakcje nietypowe dla danego sprawcy, powoduje wytrącenie psychiki zdrowego człowieka ze stanu równowagi, w rezultacie czego do głosu dochodzi dominacja sfery emocjonalnej nad kontrolującą funkcją intelektu" ${ }^{\prime 9}$.

Ustalenie, że sprawca zabójstwa tempore criminis działał w stanie silnego wzburzenia nie jest wystarczającą przesłanką do zastosowania art. 148 $\S 4$ k.k. Dla przyjęcia uprzywilejowanego typu zabójstwa konieczne jest ponadto stwierdzenie, iż wzburzenie to jest usprawiedliwione okolicznościami, przy czym podkreślić należy, że usprawiedliwiony okolicznościami może być jedynie afekt, pod wpływem którego popełniono przestępstwo. Okoliczności te w żadnym przypadku nie odnoszą się do samego faktu zabójstwa ${ }^{10}$, co wynika wprost $\mathrm{z}$ redakcji przepisu. Redukcję kary powoduje dopiero łączne wystąpienie obu przesłanek z art. 148 § 4 k.k. Kwestia okoliczności usprawiedliwiających wystąpienie afektu, choć nie mniej skomplikowana, jest jednak podejmowana $\mathrm{w}$ piśmiennictwie $\mathrm{w}$ stopniu znacznie bardziej ograniczonym.

\section{Charakter okoliczności usprawiedliwiających afekt}

W doktrynie i orzecznictwie prezentowane są zbieżne poglądy co do tego, jaki charakter - wewnętrzny, zewnętrzny czy mieszany - mają okoliczności usprawiedliwiające wystąpienie afektu. W wyroku z dnia 12 stycznia 1977 r. Sąd Najwyższy wskazał, iż okoliczności usprawiedliwiające stan silnego wzburzenia nie mogą ograniczać się jedynie do cech charakteru sprawcy i jego predyspozycji psychicznych. Okoliczności te istnieć muszą poza sprawcą, w zjawiskach zewnętrznych, na które silne wzburzenie jest reakcją, a podjęte pod jego wpływem działanie jest współmierne do wywołującej je przyczyny ${ }^{11}$. Okoliczności usprawiedliwiających afekt należy doszukiwać się więc przede wszystkim w zdarzeniach istniejących poza sprawcą, natomiast okoliczności o charakterze endogennym powinny być także brane pod uwagę, ale dopiero w drugiej

9 A. Zoll [w:] A. Zoll (red.), Kodeks karny. Czesść szczególna, t. 2. Komentarz do art. 117277 k.k., Warszawa 2013, s. 293; zob. wyrok Sądu Apelacyjnego w Katowicach z dnia 27 października 2017 r., II AKa 350/17, LEX nr 2441578.

10 Zob. A. Zoll [w:] A. Zoll (red.), Kodeks karny..., s. 294.

11 Wyrok Sądu Najwyższego z dnia 12 stycznia 1977 r., V KR 228/76, LEX nr 19246. 
kolejności. W podobnym tonie wypowiedział się Sąd Najwyższy w postanowieniu z dnia 26 listopada 2009 r., podkreślając, że silne wzburzenie jest stanem psychicznym występującym u sprawcy, polegającym na przewadze emocji nad intelektem, prowadzącym do ograniczenia kontrolującej funkcji rozumu. Przyczyn tego stanu upatrywać natomiast należy w czynnikach znajdujących się poza osobą sprawcy ${ }^{12}$. Aktualność powyższego stanowiska potwierdza w wyroku z dnia 13 lutego 2014 r. Sąd Apelacyjny w Rzeszowie, który stwierdził:

O usprawiedliwieniu silnego wzburzenia nie decyduje to, jaką odpornością psychiczną i przymiotami charakteru sprawca dysponuje, ale jaka jest przyczyna silnego wzburzenia i czy z punktu widzenia powszechnie aprobowanych norm moralnych jest ona - przynajmniej w pewnym zakresie wybaczalna ${ }^{13}$.

Nie jest bowiem prawidłowe badanie okoliczności mogących spowodować stan wzburzenia, jedynie w oparciu o kryterium subiektywne dotyczące sprawcy i jego indywidualnego systemu wartości, który najprawdopodobniej jest zaburzony ${ }^{14}$.

Takie stanowisko zdaje się przeważać także w literaturze. Słusznie zauważa K. Daszkiewicz, iż „wśród tych okoliczności, które poddaje się wartościującym ocenom” nie może zabraknąć okoliczności zewnętrznej, nie musi być to jednak jedyna okoliczność usprawiedliwiająca afekt ${ }^{15}$. Podobny pogląd prezentuje M. Tarnawski, który stwierdza, że „reakcja w postaci silnego wzburzenia jest swoistą wypadkową oddziaływania dwóch czynników: zewnętrznego - w postaci bodźca sytuacyjnego, oraz wewnętrznego - w postaci stanu osobowości sprawcy czynu zabronionego"16.

12 Zob. postanowienie Sądu Najwyższego z dnia 26 listopada 2009 r., IV KK 128/09, LEX nr 598249; wyrok Sądu Apelacyjnego w Krakowie z dnia 13 października 2015 r., II AKa 199/15, LEX nr 2046396.

13 Wyrok Sądu Apelacyjnego w Rzeszowie z dnia 13 lutego 2014 r., II AKa 4/14, LEX nr 1433830.

14 Zob. wyrok Sądu Apelacyjnego w Katowicach z dnia 14 stycznia 2016 r., II AKa 493/15, LEX nr 2023119.

15 Zob. K. Daszkiewicz, Przestępstwa z afektu..., s. 108. Autorka podkreślając powiązanie afektu z wywołującą go przyczyną, która zarazem może być uznana za usprawiedliwioną okoliczność z art. 148 § 4 k.k., określa zabójstwo z afektu jako przestępstwo sytuacyjne.

${ }_{16}$ M. Tarnawski, Zabójstwa uprzywilejowane w ujęciu polskiego prawa karnego, Poznań 1981, s. 52. 
Większość przedstawicieli doktryny podkreśla konieczność istnienia okoliczności usprawiedliwiających afekt poza sprawcą, nie wykluczając przy tym możliwości doszukiwania się ich w predyspozycjach psychicznych sprawcy. Dominuje więc teza, której nie można odmówić racji, iż okoliczności usprawiedliwiające silne wzburzenie mogą mieć charakter wyłącznie zewnętrzny lub mieszany ${ }^{17}$. W odosobnieniu pozostaje pogląd Z. Hołdy, który ogranicza okoliczności usprawiedliwiające afekt jedynie do zdarzeń zewnętrznych ${ }^{18}$.

Bezsprzecznym jest, iż okoliczności usprawiedliwiające stan silnego wzburzenia, powinny być rozpatrywane z perspektywy norm moralnych i zasad współżycia społecznego. Nie każdy bowiem afekt zasługuje na usprawiedliwienie. Trafnie wyjaśnił to Sąd Najwyższy w wyroku z dnia 5 sierpnia 1971 r. stwierdzając:

Żądanie ustawy, by silne wzburzenie było usprawiedliwione okolicznościami, należy rozumieć $\mathrm{w}$ ten sposób, że zastosowanie kwalifikacji z art. 148 $\S 2$ k.k. [obecnie 148 § 4 k.k. - K.Z.] uzasadnia nie każdy afekt, lecz tylko taki, który powstał w wyniku szczególnej sytuacji motywacyjnej, i to takiej, która uzasadnia jego powstanie, a tym samym w pewnym stopniu „usprawiedliwia" działanie sprawcy. Kodeks więc odwołuje się do oceny moralnej działania w afekcie za zasługujące na mniejsze potępienie, inne zaś nakazuje traktować jako zwykłe zabójstwo określone $\mathrm{w}$ art.148 § 1 k.k. ${ }^{19}$

Orzecznictwo Sądu Najwyższego jest w kwestii tej jednolite i konsekwentne. Dobitne stanowisko wyrażone w wyroku Sądu Najwyższego z dnia 15 marca 1972 r., iż ocena, czy silne wzburzenie było usprawiedliwione okolicznościami, powinna opierać się na przesłankach etycznych i zasadach współżycia społecznego ${ }^{20}$, powtarzane jest w wielu kolejnych orzeczeniach tego organu ${ }^{21}$.

W doktrynie wskazuje się, iż silne wzburzenie z art. $148 \S 4$ k.k. może zasługiwać na pewne zrozumienie z punktu widzenia zasad moralnych

17 Zob. A. Zoll, Kodeks karny..., s. 295; J. Giezek [w:] J. Giezek (red.), Kodeks karny: część szczególna. Komentarz, Warszawa 2014, s. 175.

18 Zob. Z. Hołda, Glosa do wyroku SN z dnia 8 września 1972 roku, „Nowe Prawo” 1973, nr 7/8, s. 1188.

19 Wyrok Sądu Najwyższego z dnia 5 sierpnia 1971 r., IV KR 144/71, LEX nr 18343.

20 Zob. wyrok Sądu Najwyższego z dnia 15 marca 1972 r., III KR 4/72, LEX nr 18448.

21 Zob. wyrok Sądu Najwyższego z dnia 16 grudnia 1982 r., I Kr 289/ 82, LEX nr 63936; wyrok Sądu Najwyższego z dnia 2 maja 1986 r., IV KR 119/86, LEX nr 63605. 
z tego powodu, że jest współmierne do przyczyny, która je wywołała ${ }^{22}$. Ze względu na wymóg współmierności reakcji do bodźca, podkreśla się w piśmiennictwie i orzecznictwie, że przyczyna będąca impulsem do powstania afektu, a która może zostać uznana za okoliczność usprawiedliwiającą, nie może być mało istotna. Słusznie zauważył Sąd Apelacyjny we Wrocławiu w wyroku z dnia 9 maja 2012 r., iż jako źródła powstania i narastania afektu, prowadzące do popełnienia jednej z najcięższych zbrodni zabójstwa, nie mogą być traktowane błahe przyczyny sytuacji konfliktowej ${ }^{23}$. Celnie jednak dostrzeżono w doktrynie, że możliwe są sytuacje wyjątkowe będące odstępstwem od tej reguły. Zdanie takie prezentuje K. Daszkiewicz, która zwraca uwagę, iż w opracowaniach z zakresu psychologii niejednokrotnie jest mowa o gwałtownych wybuchach afektu jako reakcji na bodźce błahe ${ }^{24}$. Stanowisko takie prezentowane jest również w judykaturze. Jak stwierdził Sąd Apelacyjny w Białymstoku w wyroku z dnia 18 czerwca 2015 r., może się zdarzyć, że „napięcie emocjonalne narasta przez dłuższy czas, znajdując ujście w nagłym wybuchu nawet pod wpływem pozornie błahego bodźca. W takim przypadku afekt fizjologiczny występuje w momencie kulminacyjnym spiętrzenia emocji, co można określić jako efekt kropli przelewającej czarę"25.

Nie ma także wątpliwości co do tego, że okoliczność usprawiedliwiająca stan silnego wzburzenia musi istnieć w rzeczywistości, a nie być wytworem fantazji sprawcy. Jasno dał temu wyraz Sąd Najwyższy w wyroku z dnia 23 maja 1983 r., stwierdzając, że silnego wzburzenia nie można uznać za usprawiedliwione okolicznościami, jeżeli przyczyna, która je wywołała, nie istniała realnie a jedynie w wyobraźni sprawcy ${ }^{26}$. Wobec tego tę przesłankę powinno się oceniać wprawdzie z uwzględnieniem subiektywnych odczuć sprawcy, ale przede wszystkim według kryteriów

22 A. Zoll, Kodeks karny..., s. 294.

${ }^{23}$ Zob. wyrok Sądu Apelacyjnego we Wrocławiu z dnia 9 maja 2012 r., II AKa 113/12, LEX nr 1164280.

24 Zob. K. Daszkiewicz, Przestęstwa przeciwko życiu i zdrowiu: komentarz, Warszawa 2000, s. 176. Autorka podkreśla jednak, że reakcja w postaci afektu fizjologicznego na błahy bodziec najczęściej ma miejsce w sytuacji, gdy impuls wywołujący silne wzburzenie nie jest pierwszym, ale jednym z kolejnych, a człowiek znajduje się „w swoistym pogotowiu do takiego reagowania".

${ }^{25}$ Wyrok Sądu Apelacyjnego w Białymstoku z dnia 18 czerwca 2015 r., II AKa 95/15, LEX nr 1793791.

26 Zob. wyrok Sądu Najwyższego z dnia 23 maja 1983 r., II KR 104/83, LEX nr 19894. 
obiektywnych ${ }^{27}$. Pogląd ten znajduje odzwierciedlenie w orzecznictwie sądów powszechnych. Jak wskazał Sąd Apelacyjny w Krakowie w wyroku z dnia 10 grudnia 2013 r.:

Do przyjęcia, że sprawca popełnił przestępstwo zabójstwa w typie uprzywilejowanym $z$ art. $148 \S 4$ k.k. konieczne jest wykazanie, że silne wzburzenie ma swoje usprawiedliwienie $\mathrm{z}$ punktu widzenia ocen moralnych $\mathrm{w}$ zaistniałych okolicznościach; że przyczyna afektu jest według kryteriów obiektywnych i zaaprobowanych norm moralnych przynajmniej w pewnym zakresie - wybaczalna ${ }^{28}$.

Sąd Apelacyjny w Katowicach w wyroku z dnia 23 maja 2013 r., podkreślił ponadto, iż za okoliczność z art. 148 § 1 k.k. nie może być uznane działanie $\mathrm{z}$ zamiarem nagłym, gdyż stanowiłoby to niedopuszczalne uproszczenie oceny zachowania ${ }^{29}$. Sąd Najwyższy podobne stanowisko wyraził w wyroku z dnia 5 kwietnia 1979 r., wskazując, że przez okoliczności usprawiedliwiające stan silnego wzburzenia rozumieć należy tylko te okoliczności, które pozwalają stan ten usprawiedliwić według kryteriów obiektywnych, a nie jedynie w subiektywnym odczuciu sprawcy ${ }^{30}$. Pogląd ten zasługuje na aprobatę, choć z drugiej strony nie można, jak już była mowa, całkowicie zapominać o odczuciach sprawcy związanych z sytuacją, która wywołała u niego afekt. Jak zauważył bowiem Sąd Najwyższy w wyroku z dnia 19 grudnia 1978 r. wzburzenie jest usprawiedliwione okolicznościami, gdy stanowi reakcję na ciężką krzywdę doznaną ze strony osoby, na której życie sprawca się targnął1 .

W orzecznictwie Sądu Najwyższego wielokrotnie podkreślano, iż okoliczności usprawiedliwiających stan silnego wzburzenia nie można doszukiwać się w zdarzeniach, które są spowodowane bądź zawinione wyłącznie lub w przeważającej mierze przez samego sprawcę zabójstwa.

27 W doktrynie przesłankę, aby silne wzburzenie było usprawiedliwione okolicznościami, określa się nawet mianem „przesłanki obiektywnej”, zob. A. Golonka, Niepoczytalność i poczytalność ograniczona, Warszawa 2013, s. 449.

28 Wyrok Sądu Apelacyjnego w Krakowie z dnia 10 grudnia 2013 r., II AKa 241/13, LEX nr 1403740.

${ }^{29}$ Zob. wyrok Sądu Apelacyjnego w Katowicach z dnia 23 maja 2013 r., II AKa 127/13, LEX nr 1331013.

30 Wyrok Sądu Najwyższego z dnia 5 kwietnia 1979 r., II KR 63/79, LEX nr 21808.

31 Zob. wyrok Sądu Najwyższego z dnia 19 grudnia 1978 r., III KR 226/78, LEX nr 21791. 
Stwierdził to Sąd Najwyższy m.in. w wyroku z dnia 5 stycznia 1982 r., dodając przy tym, że okoliczności usprawiedliwiające afekt „muszą być wywołane takim zachowaniem się pokrzywdzonego, które w świetle powszechnie przyjętych norm moralnych lub zasad współżycia społecznego ocenić należałoby krytycznie" ${ }^{32}$. W wyroku z dnia 6 kwietnia 1981 r. Sąd Najwyższy wskazał ponadto:

Zgodnie z ustaloną linią orzecznictwa sądowego i poglądami doktryny, okoliczności te po pierwsze muszą być w jakimś stopniu wywołane zachowaniem się pokrzywdzonego i to takim, które w świetle powszechnie przyjętych norm moralnych czy zasad współżycia społecznego ocenić należałoby krytycznie (np. prowokacja, zdrada małżeńska), a po wtóre podlegają one wartościowaniu z tego punktu widzenia, czy nie pozostały one w rażącej dysproporcji w stosunku do działania sprawcy ${ }^{33}$.

\section{Udział biegłych w ocenie okoliczności wywołującej afekt}

Na przestrzeni ostatnich lat $\mathrm{w}$ judykaturze podkreśla się, że o ile udział biegłych w ustaleniu, czy sprawca zabójstwa działał w stanie silnego wzburzenia, może się okazać nad wyraz pomocny dla sądu, o tyle nie jest zasadne ich powołanie w celu rozstrzygnięcia, czy afekt jest usprawiedliwiony okolicznościami. Jak celnie wskazał Sąd Apelacyjny w Katowicach w wyroku z dnia 23 lutego 2012 r., silne wzburzenie jest wprawdzie związane ze sferą psychiki ludzkiej, natomiast „[...] okoliczności, które je usprawiedliwiają winny być oceniane pod względem moralnym i społecznym. Jest to zatem sfera ocen, gdzie jedynym uprawnionym podmiotem do ich dokonywania jest sąd orzekający w sprawie" 34 . Wypowiadanie się biegłych psychologów bądź psychiatrów w tej kwestii, byłoby całkowicie nieuzasadnione. Takie rozwiązanie nie znajduje bowiem poparcia w przepisach. Słusznie stwierdził Sąd Najwyższy w postanowieniu z dnia 4 lutego 2014 r., iż ustalenie, czy wystąpiły okoliczności usprawiedliwiające stan silnego wzburzenia, sprowadza się do ustaleń faktycznych,

32 Wyrok Sądu Najwyższego z dnia 5 stycznia 1982 r., II KR 327/81, LEX nr 17407.

33 Wyrok Sądu Najwyższego z dnia 6 kwietnia 1981 r., I KR 30/81, LEX nr 17318.

34 Wyrok Sądu Apelacyjnego w Katowicach z dnia 23 lutego 2012 r., II AKa 11/12, LEX nr 1171010. 
które oceniane są przez sąd na podstawie przeprowadzonych dowodów, wiedzy prawniczej i doświadczenia życiowego ${ }^{35}$. Sąd ten w cytowanym orzeczeniu podkreślił ponadto, iż jedynie w skrajnie skomplikowanych przypadkach pomocne mogą być opinie biegłych, lecz nie z dziedziny psychologii lub psychiatrii, ale biegłych socjologów moralności i obyczajowości. Stanowisko takie pojawiło się w orzecznictwie Sądu Najwyższego znacznie wcześniej. W wyroku z dnia 30 stycznia 1974 r., stwierdził:

[...] okoliczności usprawiedliwiające są okolicznościami faktycznymi, usprawiedliwiającymi przede wszystkim na podstawie norm moralnych i obyczajowych ów stan silnego wzburzenia pod wpływem którego dokonano zabójstwa. Do ustalenia czy wystąpiły tego rodzaju okoliczności z reguły dochodzi sąd orzekający na podstawie przeprowadzonych dowodów, opierając się na wiedzy prawniczej i doświadczeniu życiowym. W szczególnie zaś skomplikowanych przypadkach pomocne mogą być opinie biegłych - socjologów moralności i obyczajowości w zakresie ustalenia czy wystąpiły owe okoliczności usprawiedliwiające ${ }^{36}$.

W świetle obecnych wątpliwości związanych z kwestią udziału biegłych przy ustalaniu jakie okoliczności można uznać za usprawiedliwiające afekt, stanowisko to wciąż zachowuje aktualność. W postanowieniu z dnia 14 stycznia 2016 r. Sąd Najwyższy zdecydowanie podkreślił, iż ocena, czy okoliczności, które doprowadziły do silnego wzburzenia, były usprawiedliwione, jest oceną prawną, a nie psychologiczną ${ }^{37}$.

Jak celnie dostrzeżono $\mathrm{w}$ doktrynie, działanie pod wpływem afektu wymaga rozgraniczenia od jego oceny ${ }^{38}$. Innymi słowy, to iż obiektywnie afektywnej reakcji sprawcy nie da się usprawiedliwić z punktu widzenia norm moralnych i zasad współżycia społecznego, nie wyklucza tego, że sprawca $\mathrm{w}$ chwili popełnienia zabójstwa znajdował się w stanie silnego wzburzenia. Oczywiście nie można wtedy zakwalifikować czynu jako przestępstwa uprzywilejowanego. Jest to natomiast okoliczność mogąca mieć istotne znaczenie $\mathrm{w}$ sprawie, dlatego nie powinno się jej elimino-

35 Zob. postanowienie Sądu Najwyższego z dnia 4 lutego 2014 r., II KK 290/13, LEX nr 1427462; postanowienie Sądu Najwyższego z dnia 14 stycznia 2016 r., V KK 361/15, LEX nr 1976257.

36 Wyrok Sądu Najwyższego z dnia 30 stycznia 1974 r., II KR 194/73, LEX nr 21611.

37 Zob. wyrok Sądu Najwyższego z dnia 14 stycznia 2016 r., V KK 361/15, LEX nr 1976257.

38 Zob. K. Daszkiewicz, Przestępstwa przeciwko życiu i zdrowiu..., s. 173. 
wać z tego powodu, iż sprawca działał z ewidentnie niskich pobudek. Wskazuje się więc, że prawidłowym działaniem organów postępowania karnego jest najpierw ustalenie, czy sprawca działał w afekcie, a dopiero w następnej kolejności ocena, czy u jego podstaw leżały okoliczności o usprawiedliwiającym charakterze $\mathrm{e}^{39}$.

\section{Zabójstwo z afektu osoby trzeciej}

W kwestii okoliczności usprawiedliwiających stan silnego wzburzenia, najwięcej kontrowersji wzbudza podnoszony niejednokrotnie w orzecznictwie wymóg pochodzenia źródła afektu od samej ofiary. Sąd Najwyższy w wyroku z dnia 16 czerwca 1972 r. wyraził pogląd, iż silne wzburzenie może być usprawiedliwione okolicznościami wtedy, gdy sprawca zabójstwa dozna dostatecznie silnej krzywdy ",ale nie od kogokolwiek, lecz tylko od pokrzywdzonego" i stwierdził ponadto, że "Nie można [...] pogodzić się z takim stanowiskiem, aby sprawca spotkał się - przykładowo rzecz biorąc - z bolesną zniewagą ze strony A., a gniew, oburzenie wyładował w ten sposób, że zabił B. czy C. - i działał przy tym pod wpływem silnego wzburzenia usprawiedliwionego okolicznościami" ${ }^{40}$. Już we wcześniejszym wyroku z dnia 8 października 1971 r., Sąd Najwyższy kategorycznie stwierdził:

Przepis art. $148 \S 2$ k.k. [obecnie art. $148 \S 4$ k.k. - K.Z.] ma zastosowanie jedynie wówczas, gdy istnieje związek między zachowaniem się pokrzywdzonego i stanem silnego wzburzenia oskarżonego, gdy stan silnego wzburzenia jest wynikiem krzywdy doznanej przez oskarżonego ze strony pokrzywdzonego ${ }^{41}$.

Stanowisko takie wzbudziło jednak słuszne wątpliwości doktryny. Cytowanym wypowiedziom Sądu Najwyższego nie można przyznać racji,

39 Zob. K. Wiak [w:] K. Wiak A. Grześkowiak (red.), Kodeks karny..., s. 866; postanowienie Sądu Najwyższego z dnia 29 maja 2003 r., III KK 74/03, LEX nr 80701.

40 Wyrok Sądu Najwyższego z dnia 16 czerwca 1972 r., II KR 64/72, LEX nr 21494.

${ }^{41}$ Wyrok Sądu Najwyższego z dnia 8 października 1971 r., II KR 196/71, LEX nr 16641. Jak podaje K. Daszkiewicz, pogląd taki „zakorzenił się” w polskim prawie karnym już podczas obowiązywania Kodeksu karnego z 1932 r., zob. K. Daszkiewicz, Przestępstwa $z$ afektu..., s. 122. 
przede wszystkim z tego względu, że ustawodawca w żadnym miejscu nie stawia wymogu, aby dla zastosowania art. $148 \S 4$ k.k., silne wzburzenie usprawiedliwione okolicznościami pochodziło od ofiary ${ }^{42}$. W literaturze wskazuje się, że wobec tego możliwa jest kwalifikacja zabójstwa jako popełnionego pod wpływem afektu w sytuacji, gdy „silne wzburzenie wywołało zachowanie się innej osoby niż pokrzywdzony, jeżeli tylko istnieje związek pomiędzy tym zachowaniem a afektem sprawcy"43. Jak słusznie bowiem zauważył M. Szerer, nie jest zasadne uzależnianie zastosowania art. $148 \S 4$ k.k. od tego, czy sprawca precyzyjnie i racjonalnie pokieruje swym działaniem, gdyż istotą afektu jest właśnie to, że ową racjonalność postępowania wyklucza ${ }^{44}$. Podobny pogląd prezentuje także K. Daszkiewicz, zdaniem której „[...] ze względu na charakter działania emocjonalnego nie jest słuszny warunek, aby okoliczność usprawiedliwiająca afekt, zawsze w każdej sytuacji pochodziła od ofiary" ${ }^{45}$. Autorka podkreśla, że nie jest uzasadnione uznanie za nieusprawiedliwione okolicznościami działanie w afekcie sprawcy, który w konkretnej sytuacji nawet nie przewidywał, że swoim czynem ugodzi także w osobę trzecią, lub stało się to niejako przez przypadek, np. sprawca oddaje strzał w kierunku osoby, która była źródłem afektu, ale chybia i trafia przechodzącą obok nieznaną osobę $e^{46}$. Powodowałoby to także komplikacje w sytuacji, gdy sprawca działający w stanie silnego wzburzenia, swoim czynem skierowałby zamach na życie więcej niż jednej osoby ${ }^{47}$. Na poparcie takiej tezy wskazywano, iż ma ona swe uzasadnienie w psychologii i psychiatrii, a mianowicie $\mathrm{w}$ zjawisku tzw. irradiacji afektu - przemieszczenia reakcji agresywnej na inny obiekt, niż ten, który afekt wywołał ${ }^{48}$.

Przedstawione argumenty prowadzą do jednoznacznego wniosku, iż uznanie silnego wzburzenia za usprawiedliwione okolicznościami, tylko w sytuacji gdy afekt powoduje ofiara, nie jest prawidłowe. W ocenie, czy takie usprawiedliwienie rzeczywiście zachodzi decydujące powinno być kryterium, czy z obiektywnego punktu widzenia czyn sprawcy jest cho-

42 Zob. A. Golonka, Niepoczytalność..., s. 450; Z. Hołda, Glosa do wyroku SN..., s. 1186.

43 A. Golonka, Niepoczytalność..., s. 450-451.

44 Zob. M. Szerer, Glosa do wyroku SN z 29 września 1971 r., „Orzecznictwo Sądów Polskich i Komisji Arbitrażowych" 1972, nr 7/8, s. 374.

45 K. Daszkiewicz, Przestępstwa z afektu..., s. 126.

46 Zob. tamże, s. 124, 128.

47 Zob. tamże, s. 128.

48 Zob. A. Golonka, Niepoczytalność..., s. 451. 
ciaż w pewnym stopniu zrozumiały, wybaczalny i zasługuje na mniejsze społeczne potępienie. Zawężanie stosowania przepisu art. $148 \S 4$ k.k. tylko do zdarzeń, w których ofiarą jest prowokator afektu, mogłoby doprowadzić do sytuacji, że sprawcy, których czyn z punktu widzenia etyczno-moralnego powinien być oceniony łagodniej, odpowiadaliby za zbrodnię i ponosili niewspółmiernie wysoką karę, także w kontekście odrzucenia społecznego. Ustawodawca wprowadzając do Kodeksu karnego z 1969 r. dodatkową przesłankę w postaci wymogu, aby afekt był usprawiedliwiony okolicznościami miał na celu ograniczenie stosowania przepisu ${ }^{49}$. Nie ma natomiast podstaw ku temu, aby wyciągnąć wniosek, iż ma to być ograniczenie tak daleko idące.

Krytyczne wypowiedzi przedstawicieli doktryny i - zdawałoby się oczywiste argumenty nie spowodowały jednak zmian w judykaturze. O ile w piśmiennictwie podkreśla się wciąż, że ofiarą zabójstwa z afektu jest najczęściej osoba, która silne wzburzenie wywołała, o tyle nie przesądza się jednoznacznie, iż nie może on zostać spowodowany także przez działanie innej niż pokrzywdzony osoby ${ }^{50}$. W orzecznictwie aprobuje się nadal istnienie wymogu, aby dla zastosowania kwalifikacji z art. 148 § 4 k.k. źródłem silnego wzburzenia sprawcy była ofiara. Taka praktyka sądów powszechnych jest tym bardziej zastanawiająca, że dla uzasadnienia słuszności powyższego rozwiązania nie przywołują argumentów merytorycznych, ale akcentują, iż jest to ugruntowany pogląd Sądu Najwyższego $^{51}$. Biorąc pod uwagę to, że w przepisie art. $148 \S 4$ k.k. ustawodawca nie stawia wprost warunku, aby pokrzywdzonym była osoba, która przyczyniła się do powstania afektu u sprawcy, a także, iż większość

49 Na gruncie przepisu art. 225 § 2 Kodeksu karnego z 1932 r., jedynym wymogiem uznania zabójstwa za typ uprzywilejowany było ustalenie, iż sprawca działał pod wpływem silnego wzruszenia. Tak szerokie ujęcie przepisu budziło wiele zastrzeżeń. Doprowadziło bowiem do sytuacji, w której w uprzywilejowany, łagodniejszy sposób traktowani mogli być także sprawcy działający z niskich, niemających usprawiedliwienia moralnego i społecznego pobudek, a ponadto sprawiło, że przepis, który w założeniu miał dotyczyć przypadków wyjątkowych, przez zbyt nieostre określenie dyspozycji był niemal nadużywany, zob. P. Horoszowski, Zabójstwo z afektu, Warszawa 1947, s. 53-54; A. Gubiński, Zabójstwo pod wptywem silnego wzruszenia, Warszawa 1961, s. 13-14; wyrok Sądu Najwyższego z dnia 27 marca 1933 r., III K 147/33, LEX nr 75843.

50 Zob. A. Golonka, Niepoczytalność..., s. 451-452.

51 Zob. wyrok Sądu Apelacyjnego w Gdańsku z dnia 16 lipca 2013 r., II AKa 187/13, LEX nr 1388782; wyrok Sądu Apelacyjnego w Warszawie z dnia 5 września 2006 r., II AKa 220/06, LEX nr 219067. 
przedstawicieli doktryny ma $\mathrm{w}$ tym zakresie zdanie zupełnie odmienne niż Sąd Najwyższy, tak uargumentowanego postulatu nie sposób uznać za poprawny.

\section{Analiza okoliczności mogących zostać uznane za usprawiedliwiające stan silnego wzburzenia}

Z oczywistych powodów, stworzenie wyczerpującego katalogu okoliczności usprawiedliwiających stan silnego wzburzenia nie jest możliwe. Nie ma wątpliwości co do tego, że owe okoliczności nie mogą być rozważane in abstracto, ale muszą wynikać z konkretnych ustaleń faktycznych w danej sprawie. Jak wskazał Sąd Najwyższy w wyroku z dnia 14 grudnia 1973 r., ,[...] kryteria oceny, czy silne wzburzenie jest usprawiedliwione konkretnymi okolicznościami danej sprawy, wywodzą się z przesłanek psychologicznych i moralnych oraz zasad współżycia społecznego" ${ }^{52}$, a powinnością sądu jest każdorazowe ustalenie ich jako podstawy do przypisania zabójstwa oskarżonemu w postaci uprzywilejowanej ${ }^{53}$. Nie można zatem z góry założyć, że dana okoliczność będzie w każdym przypadku bezwzględnie usprawiedliwiać stan silnego wzburzenia.

Do okoliczności usprawiedliwiających stan silnego wzburzenia w orzecznictwie najczęściej zalicza się takie zachowanie się pokrzywdzonego, które w świetle powszechnie przyjętych norm etycznych i zasad współżycia społecznego, należałoby ocenić krytycznie ${ }^{54}$. Mogą to być np. ustawiczne drażnienie, prowokowanie, zdrada małżeńska, ciężka obelga lub posądzenie o czyn hańbiący ${ }^{55}$. Jako usprawiedliwiony może zostać także uznany afekt wywołany długotrwałym znęcaniem się nad sprawcą przez jego późniejszą ofiarę lub wzburzenie spowodowane zadaniem mu innej wielkiej i nieuzasadnionej krzywdy ${ }^{56}$.

52 Wyrok Sądu Najwyższego z dnia 14 grudnia 1973 r., III KR 303/73, LEX nr 18742.

53 Zob. tamże.

54 Zob. wyrok Sądu Najwyższego z dnia 30 listopada 1972 r., I KR 243/72, LEX nr 18591.

55 Zob. tamże.

56 Zob. wyrok Sądu Najwyższego z dnia 18 listopada 1971 r., III KR 186/71, LEX nr 63747. 
Ogólne założenia dotyczące okoliczności usprawiedliwiających stan silnego wzburzenia, dobrze oddaje orzeczenie Sądu Apelacyjnego w Katowicach dotyczące zdrady małżeńskiej. Sąd ten w wyroku z dnia 30 marca 1995 r. stwierdził:

Na gruncie art. 148 § 2 k.k. [obecnie art. 148 § 4 k.k. - K.Z.] przyjąć należy, iż dopuszczanie się zdrady przez współmałżonka, późniejszej ofiary zabójstwa, może usprawiedliwiać silne wzburzenie sprawcy zabójstwa tylko wówczas, gdy krzywdy wyrządzone mu tą zdradą - mierzone także kryteriami etycznymi i społecznymi - będą oceniane jako szczególnie duże (znaczne). Konieczne jest zatem ustalenie nie tylko tego, że do zdrady rzeczywiście doszło i że spowodowała ona autentyczne i głębokie cierpienie psychiczne zabójcy, ale także tego, że ze społecznego i etycznego punktu widzenia, zdrada ta nie znajduje żadnego usprawiedliwienia (zrozumienia) i jako taka, powinna spotkać się z jednoznaczną dezaprobatą i potępieniem ${ }^{57}$.

Orzeczenie to jasno obrazuje, że na gruncie art. $148 \S 4$ k.k. istotne jest nie tyle wystąpienie jakiejś określonej okoliczności, ale to, czy dane zdarzenie wywołało u sprawcy rzeczywistą krzywdę, a także czy w danym układzie sytuacyjnym zasługuje ono na wybaczenie, czy też nie. Może się przecież okazać, że zachowanie ofiary, które na pierwszy rzut oka wydaje się być wysoce naganne, $\mathrm{w}$ dużej mierze spowodowane jest jednak niewłaściwym postępowaniem sprawcy, co całkowicie zmieni obraz sytuacji.

Często przytaczanym $\mathrm{w}$ doktrynie przykładem okoliczności usprawiedliwiającej afekt jest znęcanie się nad sprawcą przez jego późniejszą ofiarę. Nie ma wątpliwości co do tego, iż jest to przykład trafny. Znęcanie jest bowiem przestępstwem uregulowanym w art. $207 \S 1$ k.k. Samo ulokowanie tego przepisu w rozdziale dotyczącym przestępstw przeciwko rodzinie i opiece, świadczy o tym, iż zachowanie takie zasługuje na całkowitą dezaprobatę społeczeństwa. Istotą tego czynu jest znęcanie się fizyczne bądź psychiczne nad osobą najbliższą lub nad inną osobą pozostającą w stałym lub przemijającym stosunku zależności od sprawcy, nad małoletnim lub osobą nieporadną ze względu na jej stan psychiczny lub fizyczny. Jak wskazuje się $\mathrm{w}$ doktrynie, znęcanie się fizyczne może polegać między innymi na biciu, rzucaniu przedmiotami, zmuszaniu do przebywania na zimnie, poleceniu wykonywania upokarzających czyn-

57 Wyrok Sądu Apelacyjnego w Katowicach z dnia 30 marca 1995 r., II Akr 26/95, LEX nr 26494. 
ności czy wyrzucaniu z domu ${ }^{58}$. Znęcanie psychiczne może natomiast wchodzić $\mathrm{w}$ grę między innymi w przypadku: wyszydzania, upokarzania, znieważania, straszenia, gróźb bezprawnych, sprowadzania do mieszkania osób nieakceptowanych przez domowników (np. prostytutek czy przestępców) ${ }^{59}$. Takie zachowanie sprawcy wzbudza tym większe potępienie, z uwagi na szczególny stosunek zależności jaki łączył go z ofiarą. Uznając znęcanie za okoliczność usprawiedliwiającą afekt, Sąd Apelacyjny w Rzeszowie w wyroku z dnia 22 kwietnia 2011 r., podkreślił, iż jest to nie jednorazowy incydent, lecz trwające wiele lat wysoce naganne postępowanie pokrzywdzonego wobec najbliższych członków rodziny, polegające na zadawaniu im niezasłużonych $\mathrm{krzywd}^{60}$. W sytuacji więc, gdy ofiara przestępstwa znęcania staje się katem oprawcy, działając przy tym $w$ afekcie, z dużą dozą prawdopodobieństwa można stwierdzić, iż stan silnego wzburzenia uznany zostanie za usprawiedliwiony okolicznościami. Nie ma w tym przypadku znaczenia, czy znęcanie ma postać oddziaływania psychicznego, czy fizycznego, bowiem w obu odmianach tego przestępstwa ofiara doznaje znacznego cierpienia, a postępowanie sprawcy z punktu norm etyczno-moralnych jest nie do przyjęcia. Reakcja $\mathrm{w}$ postaci silnego wzburzenia ofiary przestępstwa znęcania $\mathrm{w}$ opisanych powyżej okolicznościach z pewnością jest współmierna do wywołującej je przyczyny i w powszechnym odczuciu usprawiedliwiona.

Jak wskazuje się w doktrynie, częstym podłożem zabójstwa z afektu jest długotrwały konflikt pomiędzy sprawcą a ofiarą ${ }^{61}$. W tym wypadku chodzi o trwające przez pewien okres czasu sytuacje, w których „uczucia osób znajdujących się w konflikcie podlegają intensyfikacji” i doprowadzają czasem do krótkich spięćc ${ }^{2}$. Podobnie jak w przypadku znęcania, gdzie jeden z kolejnych incydentów doprowadza do wybuchu afektu, kumulowanie się sytuacji konfliktowych jest podłożem sprzyjającym wystąpieniu silnej emocjonalnej reakcji. Konflikt nie może jednak usprawiedliwiać afektu, jeżeli jego źródłem jest wyłącznie sprawca zabójstwa. Jak słusznie wskazał Sąd Najwyższy w wyroku z dnia 11 lipca 1974 r.:

58 Zob. M. Mozgawa [w:] M. Mozgawa (red.), Kodeks karny. Komentarz, Warszawa 2013, s. 489.

59 Zob. tamże.

60 Zob. wyrok Sądu Apelacyjnego w Rzeszowie z dnia 22 kwietnia 2011 r., II AKa 34/10, LEX nr 1015912.

61 Zob. K. Daszkiewicz, Przestepstwa z afektu..., s. 81-82.

62 Tamże. 
Silne wzburzenie w rozumieniu art. 148 § 2 k.k. [obecnie art. 148 § 4 k.k. K.Z.] nie może być uznane za usprawiedliwione, jeżeli przyczyną tego afektu jest zdarzenie (zjawisko, konflikt) zawinione wyłącznie lub w przeważającym stopniu przez samego sprawcę, a nie zachowanie się osoby, przeciwko życiu której zwrócone jest przestępne działanie sprawcy ${ }^{63}$.

Ostrożnie należy podchodzić do kwestii uznania za okoliczność usprawiedliwiającą afekt ciężkiej obelgi lub posądzenia o czyn hańbiący. Nie ma bowiem możliwości zastosowania art. 148 § 4 k.k. w sytuacji, gdy późniejsza ofiara zachowuje się wobec sprawcy niegrzecznie lub lekceważąco, bo afektywna reakcja sprawcy byłaby wtedy oczywiście nieadekwatna do bodźca. Błahą obelgę, jako czynnik wywołujący bardzo silną reakcję emocjonalną, Sąd Najwyższy odrzucił już w wyroku z dnia 11 lutego 1958 r. ${ }^{64}$ Orzeczenie to można odnieść na zasadzie analogii do okoliczności posądzenia o czyn hańbiący. W tym miejscu warto przypomnieć, że aby powyższe zachowanie mogło zostać uznane za okoliczność usprawiedliwiającą stan silnego wzburzenia, musi być obiektywnie naganne i to na tyle, aby choć w pewnym zakresie pozwalało uznać gwałtowny postępek sprawcy za wybaczalny. Sam fakt, że sprawca poczuł się znieważony i dotknięty nie wystarczy, aby przyjąć kwalifikację z art. 148 § 4 k.k. Opisywane działanie, które może nosić znamiona przestępstwa zniewagi lub zniesławienia, ocenić należy zdecydowanie negatywnie, to jednak w każdym przypadku trzeba wnikliwie przeanalizować, czy było ono na tyle drastyczne, aby uzasadniało aż tak gwałtowną reakcję sprawcy. Nie bez znaczenia przy ocenie tej okoliczności, jest uwzględnienie w jakiej grupie społecznej funkcjonował sprawca i ofiara. To bowiem, co w jednym środowisku uznawane jest za ciężką obelgę i czyn hańbiący, niekoniecznie musi być tak postrzegane w innym.

Prowokowanie i ustawiczne drażnienie są pojęciami szerokimi, które przejawiać się mogą poprzez różne zachowania. Stownik języka polskiego prowokację określa jako „działanie mające na celu wywołanie u kogoś spodziewanej reakcji, często zgubnej dla niego w następstwach" 65 . Prowokacyjnym zachowaniem ofiary, które może zostać uznane za okoliczność usprawiedliwiającą afekt może być także ustawiczne drażnienie, rozumia-

63 Wyrok Sądu Najwyższego z dnia 11 lipca 1974 r., Rw 325/74, LEX nr 21636.

64 Zob. wyrok Sądu Najwyższego z dnia 11 lutego 1958 r., III K 1336/57, LEX nr 178612.

65 S. Skorupka, H. Auderska, Z. Łempicka (red.), Mały stownik jezzyka polskiego, Warszawa 1990, s. 636. 
ne jako bezustanne pobudzanie do gniewu, denerwowanie, irytowanie, złoszczenie, zaczepiane ${ }^{66}$. Nie ma wątpliwości, że takie czynności mają zabarwienie negatywne. Aby jednak mogły zostać uznane za okoliczności, o których stanowi art. 148 § 4 k.k. należy każdorazowo ocenić, czy reakcja afektywna jest do nich adekwatna. W literaturze wyrażono pogląd, iż

[...] tylko taka prowokacja stanowi podstawę przestępstwa uprzywilejowanego albo nadzwyczajnego złagodzenia kary, która spowodowała natychmiastowe działanie osoby sprowokowanej, podjęte z zamiarem nagłym. Działanie osoby sprowokowanej, odpowiadającej na prowokację po upływie dłuższego czasu, w warunkach, w których możliwe było przemyślane działanie, zasługiwać może $w$ konkretnej sytuacji na łagodniejsze potraktowanie jedynie w zakresie zwyczajnego wymiaru kary ${ }^{67}$.

Stanowisko to jest słuszne, ale tylko przy założeniu, że prowokacja miała charakter jednorazowy. Odpowiedź sprawcy na takie zachowanie się pokrzywdzonego po upływie pewnego czasu, uzasadnia raczej rozpatrywanie działania z niskiej pobudki - chęci zemsty. Prowokacja, czy tym bardziej ustawiczne nękanie, mogą mieć jednak charakter czynności rozłożonych w czasie, powtarzanych wielokrotnie ${ }^{68}$. Jeśli zabójstwo w afekcie stanowi bezpośrednią reakcję, nie na pierwsze, ale jedno z kolejnych prowokujących działań ofiary, zastosowanie art. $148 \S 4$ k.k. jest jak najbardziej możliwe. Będzie to sytuacja analogiczna do przypadku, kiedy podłożem wystąpienia afektu jest przestępstwo znęcania lub długotrwały konflikt pomiędzy ofiarą i sprawcą. Sprawca może znosić zachowanie pokrzywdzonego latami i dopiero jeden z wielu incydentów stanie się bodźcem wywołującym stan silnego wzburzenia.

Większość orzeczeń dotyczących przestępstwa z art. 148 \& 4 k.k., jako okoliczności usprawiedliwiające stan silnego wzburzenia podaje takie zachowanie się pokrzywdzonego, które godzi w dobra niemajątkowe sprawcy. Pojawia się zatem wątpliwość, czy w poczet okoliczności usprawiedliwiających afekt można zaliczyć także szkodę materialną. W doktrynie wskazuje się, że nie jest to wykluczone, choć niewątpliwie należy podchodzić do tej kwestii ze szczególnie dużą ostrożnością ${ }^{69}$. Nie wyłącza

\footnotetext{
66 Zob. tamże, s. 135, 869.

67 K. Daszkiewicz, Przestępstwo z premedytacja, Warszawa 1968, s. 74-75.

68 Zob. M. Tarnawski, Zabójstwa uprzywilejowane..., s. 59.

69 Zob. A. Golonka, Niepoczytalność..., s. 454.
} 
się takiej możliwości także w judykaturze. Jak wskazał Sąd Najwyższy w wyroku z dnia 7 grudnia 1972 r.:

Oczywistym jest, że pretensje natury majątkowej, zwłaszcza tego rodzaju, jak związane z bezprawnym zajęciem motocykla i odmową jego wydania $\mathrm{w}$ żadnym wypadku nie mogą być uznane za przewidzianą $\mathrm{w}$ art. 148 § 2 k.k. [obecnie $148 \S 4$ k.k. - K.Z.] okoliczność usprawiedliwiającą stan silnego wzburzenia, a zamach na życie sprawcy określonego wyżej bezprawia uznać należy za reakcję pozostającą $\mathrm{w}$ rażącej dysproporcji w stosunku do doznanej krzywdy $^{70}$.

W orzeczeniu tym, choć organ orzekający zaznaczył, iż chodzi o „pretensje natury majątkowej”, główny nacisk położył na ewidentną niewspółmierność pomiędzy postępowaniem ofiary a reakcją sprawcy. Zdaje się zatem, iż to owa dysproporcja, a nie charakter doznanej krzywdy, była powodem odmowy uznania opisanej wyżej okoliczności za usprawiedliwiającą. Warto bowiem zauważyć, iż we wcześniejszym orzeczeniu z dnia 16 czerwca 1972 r., Sąd Najwyższy wspomniał o „dostatecznie silnej krzywdzie moralnej czy materialnej" jako okoliczności usprawiedliwiającej afekt ${ }^{71}$. W świetle powyższego nasuwa się więc wniosek, iż jeśli zachowanie się ofiary można będzie ocenić jako wysoce krytyczne z punktu widzenia etyki i zasad współżycia społecznego, a wystąpienie silnego wzburzenia u sprawcy za reakcję do tego zachowania współmierną, to nie ma przeszkód ku temu, aby uznać, że sprawca działał w usprawiedliwionych okolicznościach, nawet jeśli doznana przez niego krzywda miała charakter materialny. Biorąc jednak pod uwagę słuszne stanowisko Sądu Apelacyjnego w Katowicach wyrażone w wyroku z dnia 2 grudnia 1993 r., iż:

[...] przyjęte normy moralne nie pozwalają na usprawiedliwienie zabójstwa uchylaniem się pokrzywdzonego od spłacania pożyczek, poręczonych przez oskarżonego nawet $\mathrm{w}$ sytuacji, gdy zła wola pokrzywdzonego była ewidentna, gdy zwodził, a nawet wręcz oszukiwał oskarżonego i gdy należności spiętrzyły się tak, że spłacenie ich przez oskarżonego było niemożliwe ${ }^{72}$,

należy stwierdzić, że aby uznać krzywdę materialną za okoliczność usprawiedliwiającą z art. 148 § 4 k.k., muszą zaistnieć wyjątkowe czynniki. Sytu-

70 Wyrok Sądu Najwyższego z dnia 7 grudnia 1972 r., I Kr 247/72, LEX nr 63866.

71 Zob. wyrok Sądu Najwyższego z dnia 16 czerwca 1972 r., II KR 64/72, LEX nr 21494.

72 Wyrok Sądu Apelacyjnego w Katowicach z dnia 2 grudnia 1993 r., II AKr 390/93, OSA 1994, z. 6, poz. 36. 
acje takie bez wątpienia należeć będą do rzadkości, co nie oznacza jednak, iż są niemożliwe. Wydaje się więc, że odgórna eliminacja krzywdy materialnej jako okoliczności usprawiedliwiającej afekt nie byłaby zasadna.

\section{Stan odurzenia alkoholowego i inne przesłanki dające podstawę do uznania okoliczności za nieusprawiedliwiające afekt}

Kwestią problematyczną, była niegdyś możliwość przyjęcia zabójstwa w afekcie, w sytuacji gdy sprawca znajdował się w stanie odurzenia alkoholowego. Oczywistym jest, że stan nietrzeźwości w żadnym razie nie może być rozpatrywany w ramach okoliczności usprawiedliwiającej stan silnego wzburzenia ${ }^{73}$. Po pierwsze, dobrowolne wprowadzenie się w stan nietrzeźwości wiąże się raczej ze społecznym potępieniem a nie wybaczeniem, po drugie, jest to sytuacja spowodowana wyłącznie przez sprawcę. Analogicznie sytuacja przedstawia się w przypadku zażycia substancji odurzających innych niż alkohol. Wątpliwości związane były z tym, czy można znajdować się w stanie silnego wzburzenia usprawiedliwionego okolicznościami jednocześnie pozostając pod wpływem alkoholu. Początkowo w judykaturze przyjmowano stanowisko, że afekt wywołany „zawinionym wprawieniem się w stan nietrzeźwości" powinien wyłączać możliwość kwalifikacji na podstawie art. $148 \S 4$ k.k. ${ }^{74}$ Wiązało się to z przyjęciem, iż skoro afekt fizjologiczny można uznać za inne zakłócenie czynności psychicznych z art. 31 k.k., a § 3 tego przepisu wyklucza możliwość stosowania łagodniejszych uregulowań dotyczących sprawców niepoczytalnych i w stanie poczytalności ograniczonej z paragrafów poprzedzających, w sytuacji gdy wprawili się oni w stan nietrzeźwości lub odurzenia, którego efekt w postaci zmniejszonej poczytalności przewidywali lub mogli przewidzieć, to tym bardziej okoliczność ta powinna wyłączyć możliwość zastosowania art. $148 \S 4$ k.k. ${ }^{75}$ Stanowisko takie uzasadniano względami prawidłowej wykładni i zasadami słuszności ${ }^{76}$. Jak jednak słusznie wskazano w dok-

73 Zob. wyrok Sądu Najwyższego z dnia 7 czerwca 1972 r., III KR 54/72, LEX nr 18497.

74 Zob. wyrok Sądu Najwyższego z dnia 9 sierpnia 1965 r., II KR 161/65, OSNKW 1965, nr 12.

75 Zob. K. Daszkiewicz, Przestępstwa przeciwko życiu i zdrowiu..., s. 171-172.

76 Zob. tamże. 
trynie, stanowiło to pewną nadinterpretację przepisów ${ }^{77}$. Dość szybko dostrzeżono $\mathrm{w}$ orzecznictwie, że bardziej celowe w kwestii prawidłowej kwalifikacji czynu będzie ustalenie, czy stan nietrzeźwości miał w chwili popełnienia przestępstwa wpływ na reakcję w postaci afektu, a jeśli tak to w jakim zakresie. Jeżeli był tylko czynnikiem towarzyszącym, obok innej okoliczności, która wywołała stan silnego wzburzenia i która taką reakcję może usprawiedliwić, to wydaje się, iż nie ma przeszkód w przyjęciu uprzywilejowanej kwalifikacji z art. 148 § 4 k.k. Jak zauważył Sąd Najwyższy w wyroku z dnia 10 sierpnia 1970 r., stan odurzenia alkoholem jedynie wówczas wyklucza możność zastosowania uprzywilejowanej kwalifikacji prawnej zabójstwa z afektu, gdy wykazane zostanie, że stan ten warunkował u sprawcy zabójstwa powstanie silnego wzburzenia. Jeżeli natomiast tempore criminis czynniki emocjonalne dominowały u sprawcy nad kontrolującą funkcją rozumu, nie na skutek nadużycia alkoholu, lecz z innej przyczyny, wówczas - mimo działania w stanie nietrzeźwości - może on korzystać ze wskazanej uprzywilejowanej kwalifikacji ${ }^{78}$. Pogląd ten wyraził Sąd Najwyższy także w wielu kolejnych orzeczeniach, podkreślając, iż: „Sprawca, który w chwili dokonania zabójstwa znajdował się pod wpływem alkoholu, może korzystać z uprzywilejowanej kwalifikacji prawnej [...] tylko w tych wyjątkowych wypadkach, w których silne wzburzenie zostało wywołane innymi czynnikami, nie zaś alkoholem" ${ }^{\prime 79}$, ponadto czynniki te muszą zostać uznane za takie, które niezależnie od spożycia alkoholu mogą wywołać stan silnego wzburzenia usprawiedliwionego okolicznościami ${ }^{80}$. Całkowicie wykluczone jest to $\mathrm{w}$ przypadku, "gdy podłożem całego łańcucha zdarzeń był stan nietrzeźwości oskarżonego wywołujący reakcję niewspółmierną $\mathrm{w}$ stosunku do bodźców" ${ }^{\prime 1}$. Słuszność takiego ujęcia problemu potwierdził Sąd Apelacyjny w Lublinie w wyroku z dnia 20 października 2009 r., przyjmując, iż: „Działanie nietrzeźwego sprawcy bez powodu, czy z błahego powodu nie może być uznane za działanie w stanie silnego wzburzenia tylko dlatego, że istnieje ogromna dysproporcja między powodem podjęcia przestępnego działania a jego skutkiem" ${ }^{\prime 2}$.

77 Zob. A. Golonka, Niepoczytalność..., s. 458.

78 Zob. wyrok Sądu Najwyższego z dnia 10 sierpnia 1970 r., II KR 44/70, LEX nr 21323.

79 Wyrok Sądu Najwyższego z dnia 15 sierpnia 1978 r., IV KR 212/78, LEX nr 19485.

80 Zob. wyrok Sądu Najwyższego z dnia 13 kwietnia 1973 r., II KR 9/73, LEX nr 63300.

81 Wyrok Sądu Najwyższego z dnia 5 marca 1979 r., II KR 31/79, LEX nr 17124.

82 Wyrok Sądu Apelacyjnego w Lublinie z dnia 20 października 2009 r., II AKa 201/09, LEX nr 550477. 
Wśród okoliczności nieusprawiedliwiających stan silnego wzburzenia wymienia się najczęściej, obok afektu wywołanego zażywaniem środków odurzających, także działanie sprawcy z niskich pobudek, awanturnicze usposobienie, demoralizację i brak poszanowania dla zasad współżycia społecznego ${ }^{83}$. Okoliczności te ujmowane są w orzecznictwie bardziej ogólnie niż kazuistycznie. Wskazuje się, że chodzi o takie czynniki, które, jak już była mowa, z etycznego punktu widzenia nie zasługują na wybaczenie, są wywołane wyłącznie postępowaniem sprawcy lub reakcja w postaci afektu nie jest do nich współmierna ${ }^{84}$. Uproszczając i podsumowując - są to takie okoliczności, które obiektywnie nie zasługują na usprawiedliwienie.

Osoba zdemoralizowana, czy też o usposobieniu przejawiającym się w lekceważeniu i nieprzestrzeganiu norm etycznych i moralnych, na pewno nie uzyska $\mathrm{z}$ tego powodu zrozumienia ze strony społeczeństwa, którego podstawowe zasady łamie. Postępowanie takie, wiąże się raczej z potępieniem i dezaprobatą - może być więc uznane za okoliczność obciążającą, a nie łagodzącą. Nawet gdyby było inaczej, są to okoliczności endogenne, dotyczące tylko osoby sprawcy, więc bez zaistnienia innych zewnętrznych czynników nie mogą one być rozpatrywane jako usprawiedliwiające na gruncie art. $148 \S 4$ k.k.

Obiektywnego usprawiedliwienia nie znajdzie też z pewnością działanie sprawcy z niskich pobudek. To jednak, czy dana pobudka jest niska, powinno być rozpatrywane przez pryzmat okoliczności konkretnej sprawy. Podobnie bowiem, jak nie można stwierdzić, że zaistnienie jakiejś określonej okoliczności zawsze wyczerpie dyspozycję art. 148 § 4 k.k., tak nie można jednoznacznie założyć, że konkretny bodziec popychający do działania w każdym układzie sytuacyjnym oceniony zostanie jako niski ${ }^{85}$.

83 Zob. K. Daszkiewicz, Przestępstwa przeciwko życiu i zdrowiu..., s. 175.

84 Trafny przykład niewspółmierności pomiędzy zabójstwem a okolicznością, która sprawcę do popełnienia tego czynu pchnęła, podał Sąd Apelacyjny w Krakowie. W uzasadnieniu do wyroku z dnia 10 grudnia 2013 r., stwierdził, iż: „Nie ma żadnej proporcjonalności między naruszeniem tajemnicy korespondencji i naruszeniem nietykalności cielesnej poprzez oplucie i uderzenie w twarz, a zamachem na życie człowieka", wyrok Sądu Apelacyjnego w Krakowie z dnia 10 grudnia 2013 r., II AKa 241/13, LEX nr 1403740.

85 Jak podaje K. Daszkiewicz, początkowo w orzecznictwie postulowano błędną tezę, o ujmowaniu pewnych pobudek działania, jako niezmiennie niskich w każdej sprawie. Zmiana tej koncepcji nastąpiła dopiero na początku lat 60-tych XX w., zob. K. Daszkiewicz, Przestępstwa z afektu..., s. 69. 
Zaliczone do niskich mogą zostać bez wątpienia takie pobudki jak nienawiść, chęć zemsty czy zazdrość. Działanie bowiem z takich powodów, społeczeństwo z reguły ocenia jako negatywne. Trudno też znaleźć dla nich usprawiedliwienie $\mathrm{w}$ świetle powszechnie obowiązujących norm etycznych i moralnych. Jest to jednak jak już wspomniano, uzależnione od konkretnej sytuacji. W wyroku z dnia 24 października 2013 r., Sąd Apelacyjny w Lublinie stwierdził, że za usprawiedliwione nie można uznać wzburzenia wywołanego „zdradą sprzed lat i zazdrością, zaliczaną do niskich pobudek" ${ }^{\prime 6}$. Sąd ten wskazał ponadto, że taka przyczyna silnego wzburzenia nie zasługuje na wybaczenie „z punktu widzenia powszechnie aprobowanych norm moralnych" ${ }^{87}$. W powyższej sprawie, zazdrość sprawcy powstała na tle długotrwałego konfliktu z żoną i była motorem napędowym do jego agresywnych działań, objawiających się wszczynaniem awantur, grożeniem i ubliżaniem żonie. W takich okolicznościach zrozumiałym jest, że zazdrość uznana została za niską pobudkę działania, która nie mogła usprawiedliwić afektu. W tym miejscu nie można jednak przeoczyć równie trafnego orzeczenia Sądu Najwyższego z dnia 16 listopada 1973 r., w którym podkreślił on, że „[...] zazdrość może łączyć się niekiedy z niską pobudką, lecz nie może być w każdym przypadku z taką pobudką utożsamiana, zwłaszcza zaś wtedy, gdy podłożem zazdrości jest nie nienawiść, lecz miłość do drugiego człowieka" ${ }^{88}$.

Oczywistym jest, że za usprawiedliwiającą stan silnego wzburzenia nie może zostać uznana okoliczność, która w danym przypadku stanowiła podstawę do przyjęcia, iż sprawca zabójstwa działał w wyniku motywacji zasługującej na szczególne potępienie. Jak wskazuje się w judykaturze, szczególne potępienie z art. 148 § 2 pkt 3 k.k. to pobudki „zupełnie wyjątkowe, odbiegające od przeciętnych, standardowych, jakkolwiek bardzo nagannych motywacji, budzące odruch odrazy, wywołujące silne oburzenie społeczne, determinujące potępienie ponad ramy przeciętnych reakcji negatywnych każdego człowieka" ${ }^{89}$. Wydaje się więc, iż motywacja zasługująca na szczególne potępienie stanowi niejako przeciwieństwo

86 Wyrok Sądu Apelacyjnego z Lublinie z dnia 24 października 2013 r., II AKa 143/13, LEX nr 1402923.

87 Tamże.

88 Wyrok Sądu Najwyższego z dnia 16 listopada 1973 r., II KR 158/73, OSNIK 1974, nr 4; zob. R. Kokot [w:] R.A. Stefański, Kodeks karny..., s. 912.

89 Wyrok Sądu Apelacyjnego w Krakowie z dnia 4 grudnia 2012 r., II AKa 213/12, LEX nr 1315607. 
okoliczności usprawiedliwiających stan silnego wzburzenia. Na marginesie powyższych rozważań warto jednak zauważyć, iż nie jest wykluczone popełnienie przez sprawcę pozostającego w stanie silnego wzburzenia, zabójstwa będącego jednocześnie wynikiem motywacji zasługującej na szczególne potępienie. $\mathrm{W}$ takiej jednak sytuacji czyn sprawcy powinien zostać uznany jako wypełniający znamiona kwalifikowanego typu zabójstwa, uregulowanego w przepisie art. 148 § 2 pkt 3 k.k. Jak wskazał Sąd Najwyższy w postanowieniu z dnia 29 maja 2003 r., ,"kwalifikowana poprzez szczególne okrucieństwo i motywację zasługującą na szczególne potępienie postać zabójstwa jest przestępstwem powszechnym - a nie indywidualnym”, w związku z czym „fakt działania w afekcie fizjologicznym nie może automatycznie wyłączać sprawcy z kręgu podmiotów mogących popełnić tę zbrodnię" 90 . Co za tym idzie, ocena okoliczności, które wywołały u sprawcy afekt powinna być ostatnim elementem analizy działań, za pomocą których sprawca wypełnił ustawowe znamiona przestępstwa ${ }^{91}$.

\section{Podsumowanie}

Przeprowadzona powyżej analiza orzecznictwa i piśmiennictwa dotyczącego okoliczności usprawiedliwiających stan silnego wzburzenia jednoznacznie wskazuje, iż ocena, czy dany układ sytuacyjny wyczerpie znamiona art. 148 § 4 k.k. w żadnym wypadku nie powinna być dokonywana in abstracto. Nawet okoliczności, które z pozoru wydają się być obciążającymi - po dokładnym studium przypadku mogą okazać się obiektywnie usprawiedliwiającymi afekt.

Wieloletnie funkcjonowanie wskazanego wyżej przepisu w niezmienionym kształcie pozwoliło wypracować w zakresie kluczowych aspektów omawianej instytucji - takich jak chociażby niedopuszczalności oceny okoliczności wywołujących afekt wyłącznie poprzez pryzmat subiektywnych odczuć sprawcy, czy też możliwość przyjęcia kwalifikacji z art. 148 $\S 4$ k.k. w sytuacji, gdy sprawca działał w stanie odurzenia alkoholowego - jednolitą interpretację i praktykę.

90 Postanowienie Sądu Najwyższego z dnia 29 maja 2003 r., III KK 74/03, LEX nr 80701.

91 Zob. tamże. 
Na szczególną uwagę zasługuje kwestia zabójstwa z afektu osoby trzeciej. W tym bowiem przypadku widać wyraźny rozdźwięk pomiędzy judykaturą a doktryną. Jak się jednak wydaje, odmienne stanowiska w zakresie oceny, czy dla możliwości zakwalifikowania czynu sprawcy jako przestępstwa z art. $148 \S 4$ k.k. niezbędnym jest, aby osoba wywołująca u sprawcy afekt była jednocześnie jego ofiarą, wynikają z błędnej wykładni, a nie $\mathrm{z}$ wadliwego ujęcia przepisu.

Słowa kluczowe: afekt, silne wzburzenie, okoliczności usprawiedliwiające, zabójstwo z afektu

\section{Bibliografia}

\section{Źródła prawa}

Rozporządzenie Prezydenta Rzeczypospolitej z dnia 11 lipca 1932 r. - Kodeks karny, Dz. U. z 1932 r. Nr 60, poz. 571 z późn. zm.

Ustawa z dnia 19 kwietnia 1969 r. - Kodeks karny, Dz. U. z 1969 r. Nr 13, poz. 94 z późn. zm.

Ustawa z dnia 6 czerwca 1997 r. - Kodeks karny, tekst jednolity: Dz. U. z 2018 r. poz. 1600 z późn. zm.

\section{Orzecznictwo}

Postanowienie Sądu Najwyższego z dnia 29 maja 2003 r., III KK 74/03, LEX nr 80701.

Postanowienie Sądu Najwyższego z dnia 26 listopada 2009 r., IV KK 128/09, LEX nr 598249.

Postanowienie Sądu Najwyższego z dnia 14 kwietnia 2011 r., II KK 71/11, LEX nr 794969.

Postanowienie Sądu Najwyższego z dnia 4 lutego 2014 r., II KK 290/13, LEX nr 1427462.

Postanowienie Sądu Najwyższego z dnia 14 stycznia 2016 r., V KK 361/15, LEX nr 1976257.

Wyrok Sądu Najwyższego z dnia 3 kwietnia 1933 r., I K 166/33, LEX nr 389795. Wyrok Sądu Najwyższego z dnia 13 stycznia 1956 r., IV K 1028/55, LEX nr 118613. Wyrok Sądu Najwyższego z dnia 11 lutego 1958 r., III K 1336/57, LEX nr 178612. Wyrok Sądu Najwyższego z dnia 9 sierpnia 1965 r., II KR 161/65, OSNKW 1965, nr 12.

Wyrok Sądu Najwyższego z dnia 10 sierpnia 1970 r., II KR 44/70, LEX nr 21323. Wyrok Sądu Najwyższego z dnia 5 sierpnia 1971 r., IV KR 144/71, LEX nr 18343. 
Wyrok Sądu Najwyższego z dnia 8 października 1971 r., II KR 196/71, LEX nr 16641.

Wyrok Sądu Najwyższego z dnia 18 listopada 1971 r., III KR 186/71, LEX nr 63747. Wyrok Sądu Najwyższego z dnia 15 marca 1972 r., III KR 4/72, LEX nr 18448.

Wyrok Sądu Najwyższego z dnia 7 czerwca 1972 r., III KR 54/72, LEX nr 18497.

Wyrok Sądu Najwyższego z dnia 16 czerwca 1972 r., II KR 64/72, LEX nr 21494.

Wyrok Sądu Najwyższego z dnia 30 listopada 1972 r., I KR 243/72, LEX nr 18591.

Wyrok Sądu Najwyższego z dnia 7 grudnia 1972 r., I Kr 247/72, LEX 63866.

Wyrok Sądu Najwyższego z dnia 13 lutego 1973 r., V KRN 567/72, LEX nr 64179. Wyrok Sądu Najwyższego z dnia 13 kwietnia 1973 r., II KR 9/73, LEX nr 63300.

Wyrok Sądu Najwyższego z dnia 16 listopada 1973 r., II KR 158/73, OSNIK 1974, nr 4.

Wyrok Sądu Najwyższego z dnia 14 grudnia 1973 r., III KR 303/73, LEX nr 18742. Wyrok Sądu Najwyższego z dnia 30 stycznia 1974 r., II KR 194/73, LEX nr 21611. Wyrok Sądu Najwyższego z dnia 11 lipca 1974 r., Rw 325/74, LEX nr 21636.

Wyrok Sądu Najwyższego z dnia 12 stycznia 1977 r., V KR 228/76, LEX nr 19246. Wyrok Sądu Najwyższego z dnia 15 sierpnia 1978 r., IV KR 212/78, LEX nr 19485. Wyrok Sądu Najwyższego z dnia 19 grudnia 1978 r., III KR 226/78, LEX nr 21791. Wyrok Sądu Najwyższego z dnia 5 marca 1979 r., II KR 31/79, LEX nr 17124. Wyrok Sądu Najwyższego z dnia 5 kwietnia 1979 r., II KR 63/79, LEX nr 21808. Wyrok Sądu Najwyższego z dnia 6 kwietnia 1981 r., I KR 30/81, LEX nr 17318. Wyrok Sądu Najwyższego z dnia 5 stycznia 1982 r., II KR 327/81, LEX nr 17407. Wyrok Sądu Najwyższego z dnia 16 grudnia 1982 r., I Kr 289/82, LEX nr 63936. Wyrok Sądu Najwyższego z dnia 23 maja 1983 r., II KR 104/83, LEX nr 19894. Wyrok Sądu Najwyższego z dnia 2 maja 1986 r., IV KR 119/86, LEX nr 63605. Wyrok Sądu Apelacyjnego w Katowicach z dnia 2 grudnia 1993 r., II AKr 390/93, OSA 1994, z. 6, poz. 36.

Wyrok Sądu Apelacyjnego w Katowicach z dnia 30 marca 1995 r., II Akr 26/95, LEX nr 26494.

Wyrok Sądu Apelacyjnego w Warszawie z dnia 5 września 2006 r., II AKa 220/06, LEX nr 219067.

Wyrok Sądu Apelacyjnego w Lublinie z dnia 20 października 2009 r., II AKa 201/09, LEX nr 550477.

Wyrok Sądu Apelacyjnego w Rzeszowie z dnia 22 kwietnia 2011 r., II AKa 34/10, LEX nr 1015912.

Wyrok Sądu Apelacyjnego w Katowicach z dnia 23 lutego 2012 r., II AKa 11/12, LEX nr 1171010.

Wyrok Sądu Apelacyjnego we Wrocławiu z dnia 9 maja 2012 r., II AKa 113/12, LEX nr 1164280.

Wyrok Sądu Apelacyjnego w Krakowie z dnia 4 grudnia 2012 r., II AKa 213/12, LEX nr 1315607. 
Wyrok Sądu Apelacyjnego w Katowicach z dnia 23 maja 2013 r., II AKa 127/13, LEX nr 1331013.

Wyrok Sądu Apelacyjnego w Gdańsku z dnia 16 lipca 2013 r., II AKa 187/13, LEX nr 1388782.

Wyrok Sądu Apelacyjnego z Lublinie z dnia 24 października 2013 r., II AKa 143/13, LEX nr 1402923.

Wyrok Sądu Apelacyjnego w Krakowie z dnia 10 grudnia 2013 r., II AKa 241/13, LEX nr 1403740.

Wyrok Sądu Apelacyjnego w Rzeszowie z dnia 13 lutego 2014 r., II AKa 4/14, LEX nr 1433830.

Wyrok Sądu Apelacyjnego w Katowicach z dnia 3 kwietnia 2014 r., II AKa 63/14, LEX nr 1461041.

Wyrok Sądu Apelacyjnego w Białymstoku z dnia 18 czerwca 2015 r., II AKa 95/15, LEX nr 1793791.

Wyrok Sądu Apelacyjnego w Krakowie z dnia 13 października 2015 r., II AKa 199/15, LEX nr 2046396.

Wyrok Sądu Apelacyjnego w Katowicach z dnia 14 stycznia 2016 r., II AKa 493/15, LEX nr 2023119.

Wyrok Sądu Apelacyjnego w Katowicach z dnia 27 października 2017 r., II AKa 350/17, LEX nr 2441578.

\section{Literatura}

Cora S., Zabójstwo pod wptywem silnego wzburzenia w świetle prawa $i$ psychologii, „Nowe Prawo" 1973, nr 7/8, s. 1026-1039.

Daszkiewicz K., Przestępstwa przeciwko życiu i zdrowiu. Komentarz, Warszawa 2000.

Daszkiewicz K., Przestępstwa z afektu w polskim prawie karnym, Warszawa 1982.

Daszkiewicz K., Przestępstwo z premedytacja, Warszawa 1968.

Giezek J. [w:] J. Giezek (red.), Kodeks karny: część szczególna. Komentarz, Warszawa 2014, s. 174-178.

Golonka A., Niepoczytalność i poczytalność ograniczona, Warszawa 2013.

Golonka A., Stan silnego wzburzenia jako znamię zabójstwa typu uprzywilejowanego czy okoliczność wptywajaca na zmniejszenie poczytalności sprawcy przestępstwa?, „Palestra” 2014, nr 3/4, s. 65-75.

Gubiński A., Zabójstwo pod wptywem silnego wzruszenia, Warszawa 1961.

Hołda Z., Glosa do wyroku SN z dnia 8 września 1972 roku, „Nowe Prawo” 1973, nr 7/8, s. 1186-1188.

Horoszowski P., Zabójstwo z afektu, Warszawa 1947.

Kokot R. [w:] R.A. Stefański (red.), Kodeks karny. Komentarz, Warszawa 2017, s. 876-913. 
Komisja Kodyfikacyjna Rzeczypospolitej Polskiej. Sekcja Prawa Karnego, Projekt kodeksu karnego, w redakcji przyjętej w drugiem czytaniu przez Sekcje Prawa Karnego Komisji Kodyfikacyjnej R. P. Uzasadnienie części szczególnej, t. 5, z. 4, Warszawa 1930.

Król W., Silne wzburzenie w rozumieniu art. 148 \& 4 k.k., "Prokuratura i Prawo” 2009, nr 9, s. 45-65.

Mozgawa M. [w:] M. Mozgawa (red.), Kodeks karny. Komentarz, Warszawa 2013.

Skorupka S., H. Auderska, Z. Łempicka (red.), Mały słownik języka polskiego, Warszawa 1990.

Szerer M., Glosa do wyroku SN z 29 września 1971 r., „Orzecznictwo Sądów Polskich i Komisji Arbitrażowych" 1972, nr 7/8, s. 370-374.

Tarnawski M., Zabójstwa uprzywilejowane w ujęciu polskiego prawa karnego, Poznań 1981.

Wiak K. [w:] K. Wiak, A. Grześkowiak (red.), Kodeks karny. Komentarz, Warszawa 2018, s. 844-867.

Wolter W. [w:] I. Andrejew, W. Świda, W. Wolter, Kodeks karny z komentarzem, Warszawa 1973, s. 436-439.

Zoll A. [w:] A. Zoll (red.), Kodeks karny. Część szczególna. Komentarz, Warszawa 2013, s. 290-299.

\section{CIRCUMSTANCES JUSTIFYING A STATE OF INTENSE AGITATION IN THE CASE OF HOMICIDE COMMITTED OF PASSION}

\section{Sum mary}

The subject of this study is the analysis of the term "circumstances justifying the state of strong agitation", which is one of the premises of homicide committed of passion (art. $148 \S 4$ Penal Code). Attention is paid first of all to practical aspects of this premise, including potential problems with the interpretation of art. $148 \S 4$ Penal Code. According to the author, creating a closed catalog of circumstances that in any case will be considered to justify affect is not possible. This assessment should be made in a specific case.

Key words: affect, circumstances justifying, state of strong agitation, homicide committed of passion 


\title{
ОБСТОЯТЕЛЬСТВА, ОПРАВДЫВАЮЩИЕ СОСТОЯНИЕ СИЛЬНОГО ГНЕВА ПРИ УБИЙСТВЕ В СОСТОЯНИИ АФФЕКТА
}

\author{
Резюме
}

Предметом настоящей работы является анализ обстоятельств, оправдывающих состояние сильного гнева - одна из составляющих регулируемого арт. 148 § 4 уголовного кодекса убийство в состоянии аффекта. Обращено внимание прежде всего на потенциальные проблемы интерпретации, которые может вызвать толкование этого понятия, а также на практический аспект данной организации, как, например, порядок осуществления органами юстиции соответствующих договоренностей. По мнению автора, невозможно создать исчерпывающий каталог обстоятельств, в которых в любом случае будет признан оправдывающий аффект. Эта оценка всегда должна быть совершена in concreto, на основе конкретной ситуационной системы.

Ключевые слова: аффект, сильное возбуждение, обстоятельства оправдывающие убийство в состоянии аффекта 